\title{
PENINGKATAN PENGETAHUAN KESEHATAN IBU DAN PENDIDIKAN ANAK DI DESA KIARASARI KABUPATEN BOGOR
}

\section{IMPROVEMENT OF KNOWLEDGE OF MOTHER'S HEALTH AND CHILD EDUCATION IN KIARASARI VILLAGE OF BOGOR DISTRICT}

\author{
Noer Aziza ${ }^{1)}$, Dedi Hantono ${ }^{2) *}$ \\ ${ }^{1)}$ Badan Kependudukan dan Keluarga Berencana Nasional (BKKBN) \\ email: noeraziza@bkkbn.go.id \\ ${ }^{2)}$ Fakultas Teknik, Universitas Muhammadiyah Jakarta \\ email: dedihantono@umj.ac.id
}

\begin{abstract}
ABSTRAK
Peranan ibu sangat penting dalam keluarga karena selain pekerjaan rumah tangga ibu juga memiliki peran sebagai seorang pendidik bagi anak-anaknya. Aspek kesehatan menjadi tuntutan yang sangat penting bagi ibu demi kelancaran pekerjaan yang menjadi tanggungjawabnya. Pendidikan anak terutama pada usia dini bisa dicapai melalui pendidikan formal maupun dengan bermain. Oleh karena itu kegiatan pengabdian ini merupakan bentuk usaha dalam meningkatkan pengetahuan kesehatan bagi ibu dan memfasilitasi sarana pendidikan anak. Kegiatan ini bekerjasama dengan Badan Kependudukan dan Keluarga Berencana (BKKBN) agar permasalahan serta maksud dan tujuan kegiatan ini tercapai. Kegiatan pengabdian ini memiliki 2 aspek yaitu kesehatan ibu dan pendidikan anak. Aspek kesehatan ibu dicapai melalui kegiatan penyuluhan kesehatan reproduksi dan keluarga yang diberikan oleh BKKBN sedangkan aspek pendidikan anak dicapai melalui kegiatan pembuataan taman bermain oleh Program Studi Arsitektur Universitas Muhammadiyah Jakarta. Kedua kegiatan tersebut memberi dampak yang baik bagi penduduk Desa Kiarasari, diantaranya: peningkatan pengetahuan kesehatan bagi ibu-ibu Desa Kiarasari dan semakin meningkatnya jumlah anakanak yang berkunjung ke taman bermain dan taman bacaan.
\end{abstract}

Kata kunci: Kesehatan Reproduksi, Keluarga, Ibu, Pendidikan Anak, Taman Bermain

\section{ABSTRACT}

The mother's role is very important in the family because in addition to housework, the mother also has a role as an educator for her children. The health aspect is a very important demand for mothers for the smooth running of the work for which they are responsible. Children's education, especially at an early age, can be achieved through formal education or by playing. Therefore this service activity is a form of effort in increasing health knowledge for mothers and facilitating children's education facilities. This activity is in collaboration with the Central Population and Family Planning Agency (BKKBN) so that the problems and aims and objectives of this activity are achieved. This service activity has 2 aspects, namely maternal health and children's education. The maternal health aspect is achieved through reproductive and family health counseling activities provided by the BKKBN, while the children's education aspect is achieved through the creation of a playground by the Architecture Study Program at Muhammadiyah University, Jakarta. The two activities have had a good impact on the residents of Kiarasari Village, including: increasing health knowledge for the mothers of Kiarasari Village and the increasing number of children visiting the playground and reading garden.

Keywords: Reproductive Health, Family, Mother, Children's Education, Playground

\section{PENDAHULUAN}

Hubungan emosional seorang anak

dengan ibu cenderung lebih dekat

dibandingkan dengan ayah dalam suat

Corresponding author:

$\bowtie$ dedihantono@umj.ac.id keluarga. Hal ini disebabkan pada umumnya seorang ibu banyak menghabiskan waktu dengan anak-anaknya sejak mereka kecil. Seorang ibu juga lebih luwes dalam 
mengasuh anak dibandingkan seorang ayah yang cenderung lebih kaku sehingga ibu lebih mendominasi pendidikan anak dalam rumah tangga (Bussa, Bunga, Thoomaszen, \& Kiling, 2018).

Peranan ibu dalam suatu keluarga cukup besar. Pembagian waktu pekerjaan rumah tangga dan penerapan pendidikan anak berdasarkan karakter mereka masing-masing menjadi hal yang rutin bagi seorang ibu dalam kehidupan sehari-hari. Tanggungjawab seorang ibu dalam pekerjaan rumah tangga dan mengasuh anak tersebut akan terasa semakin besar jika harus menghadapi anak yang cukup banyak. Hal tersebut memberi dampak terhadap kesehatan ibu baik fisik maupun mental. Begitu juga sebaliknya, perilaku ibu juga memberi dampak terhadap anak termasuk perilaku sehat. Oleh karena begitu besarnya peranan ibu dalam keluarga sehingga sangat penting pembekalan bagi mereka mengenai kesehatan khususnya kesehatan reproduksi demi terwujudnya generasi penerus yang berkualitas dan ketahanan keluarga (Oktomalioputri \& Darwin, 2019).

Pendidikan anak semestinya tidak luput dari perhatian terutama sejak mereka usia dini karena memiliki peran penting dalam pembentukan karakter anak (Ayuningtias, Pujiono, Nasution, \& Nasution, 2019). Pendidikan anak bisa dilakukan di luar rumah/sekolah dengan metode bermain (Syaharuddin, Pramita, \& Sirajuddin, 2019). Ruang terbuka pada suatu permukiman menjadi pilihan yang tepat untuk ruang bermain bagi anak-anak karena mudah dalam pengawasan dan pencapaian (Rafsyanjani, Rahmah, Wati, \& Hantono, 2020).

Kondisi ideal tentang kesehatan ibu dan pendidikan anak belum dimiliki oleh seluruh daerah di Indonesia. Salah satu daerah yang memiliki tingkat kesejahteraan yang rendah adalah Desa Kiarasari, Kecamatan Sukajaya, Kabupaten Bogor. Desa ini berada pada peringkat nomor 2 terendah di wilayah Kabupaten Bogor Provinsi Jawa Barat (Diansyah, Simamora, Lukiyana, \& Silalahi, 2018). Hal ini bisa dipahami karena menurut profil Pemerintah Kecamatan Sukajaya Kabupaten Bogor luas wilayah Desa Kiarasari sebesar 10.175.700 Ha selain berupa pemukiman penduduk seluas $3.290 .000 \mathrm{Ha}(32,33 \%)$ wilayah desa ini juga didominasi oleh hutan dengan luas 3.324.000 Ha $(32,66 \%)$. Adapun jenis hutan tersebut merupakan hutan lindung bukan hutan produktif sehingga tidak dapat memiliki nilai ekonomi secara langsung bagi penduduk sekitar. Oleh karena itu pekerjaan penduduk Desa Kiarasari yang berjumlah 2.092 orang didominasi oleh petani/buruh tani sebanyak 2.018 orang $(96,46 \%)$ dengan luas sawah hanya sebesar $230.000 \mathrm{Ha}(2,26 \%)^{1}$.

Kabupaten Bogor merupakan salah satu daerah yang memiliki usia pernikahan usia dini yang cukup tinggi. Pernikahan pada usia tersebut banyak membawa dampak buruk, diantaranya: perceraian, kematian pada ibu dan bayi, pola asuh ibu kepada yang anak,

1 https://kecamatansukajaya.bogorkab.go.id/desa/383, akses 6 Oktober 2020 
dan lain-lain. Untuk itulah Program Studi

Arsitektur Universitas Muhammadiyah

Jakarta bermaksud mengadakan Kegiatan

Pengabdian Masyarakat di Desa Kiarasari

Kecamatan Sukajaya di Kabupaten Bogor

Provinsi Jawa Barat melalui peningkatan pengetahuan kesehatan ibu dan pendidikan anak dalam upaya membantu pemerintah meningkatkan kesejahteraan keluarga.

\section{METODE PELAKSANAAN KEGIATAN}

Dalam kegiatan ini diperlukan metode yang direncanakan sebelum kegiatan dilaksanakan. Oleh karena kegiatan yang berlangsung memerlukan persiapan yang baik, pelaksanaan yang terarah, dan evaluasi yang tepat maka kegiatan pengabdian masyarakat ini dilaksanakan melalui 3 tahap, diantaranya:

1. Tahap Persiapan.

a. Pembentukan Tim Pelaksana, oleh karena kegiatan ini merupakan program Pengabdian Masyarakat Program Studi Arsitektur Universitas Muhammadiyah Jakarta bekerjasama dengan Badan Kependudukan dan Keluarga Berencana Nasional (BKKBN). Anggota tim internal merupakan dosen dan staf administrasi Prodi Arsitektur UMJ sedangkan anggota tim eksternal merupakan perwakilan dari kantor BKKBN.

b. Perumusan Masalah, Maksud, dan Tujuan, sehingga diharapkan kegiatan ini dapat terlaksana dengan efektif dan memberikan hasil nyata sesuai kebutuhan masyarakat setempat. c. Identifikasi Pemilihan Lokasi dan

Observasi, untuk mengenali karakteristik Desa Kiarasari di Kabupaten Bogor sehingga terpilih lokasi yang tepat untuk melaksanakan kegiatan ini. Untuk itu diperlukan survei ke lokasi yang diwakilkan oleh satu atau dua orang dosen sebelum kegiatan pengabdian dilaksanakan. Survei awal ini juga berguna untuk memberi petunjuk jalan pada anggota tim lainnya pada saat kegiatan pengabdian dilaksanakan.

d. Identifikasi Kebutuhan, data yang dibawa pada saat survei tersebut menjadi bahan identifikasi terhadap kebutuhan penduduk setempat dengan berdasarkan permasalahan, maksud, dan tujuan yang telah dirumuskan sebelumnya. Oleh karena pengabdian ini dilaksanakan oleh program studi arsitektur bekerjasama dengan badan pemerintah yang bergerak dalam bidang kependudukan dan keluarga maka identifikasi yang dicari berdasarkan ilmu keruangan serta kependudukan dan keluarga.

e. Persiapan Kegiatan, setelah identifikasi kebutuhan diketahui maka tim kegiatan pengabdian masyarakat dapat melakukan beberapa pekerjaan diantaranya sebagai berikut: pembagian tugas masing-masing anggota tim, berkoordinasi dengan seluruh stakeholder, dan menyiapkan perlengkapan yang dibutuhkan. 
2. Tahap Pelaksanaan, dilaksanakan hanya dalam satu hari kerja karena kendala jarak lokasi kegiatan yang sangat jauh. Pelaksana kegiatan pengabdian yang sebagian besar adalah dosen program studi merasa cukup sulit membagi waktu jika kegiatan ini dilakukan berulang kali.

3. Tahap Evaluasi, agar kegiatan yang telah dilaksanakan nantinya dapat berjalan sesuai dengan rencana dan tujuan kegiatan serta pelaporan kepada BKKBN sebagai bentuk pertanggungjawaban atas dana yang diberikan untuk kegiatan pengabdian masyarakat ini.

\section{HASIL DAN PEMBAHASAN}

Kegiatan Pengabdian Masyarakat Program Studi Arsitektur Universitas Muhammadiyah Jakarta (UMJ) di Desa Kiarasari Kecamatan Sukajaya Kabupaten Bogor Provinsi Jawa Barat mengajak kerjasama Badan Kependudukan dan Keluarga Berencana Nasional (BKKBN) untuk membantu merumuskan kegiatan dan pelaksanaan dalam upaya meningkatkan kesejahtaraan keluarga melalui pemberian pengetahuan tentang kesehatan ibu dan pendidikan anak. Lembaga pemerintah ini dipilih atas dasar pertimbangan bahwa BKKBN memiliki beberapa tugas, fungsi, dan program kegiatan yang berhubungan dengan kesehatan dan kesejahteraan keluarga serta kependudukan, diantaranya: keluarga berencana, kesehatan reproduksi, pembinaan keluarga balita, pembinaan keluarga remaja, pembinaan keluarga lansia, pengasuhan dan pembinaan tumbuh kembang anak, peningkatan pendapatan keluarga, penguatan kelembagaan keluarga, pemberdayaan ekonomi keluarga, dan lain-lain (Kawulur, Dengo, \& Rompas, 2015). Selain pemberian penyuluhan yang disampaikan langsung oleh perwakilan salah satu pegawai, BKKBN bersedia memberikan dana untuk kegiatan pengabdian ini. Sebagian dana ini akan dialokasikan untuk pembuatan taman bermain.

\section{Tahapan Persiapan}

Program Studi Arsitektur UMJ membentuk tim yang berasal dari internal prodi yang terdiri dari dosen dan staf administrasi sedangkan anggota tim eksternal diserahkan kepada BKKBN. Kemudian kedua tim ini melakukan pertemuan dengan perwakilan Desa Kiarasari untuk melakukan koordinasi dan merumuskan kegiatan yang akan dilakukan. Pertemuan yang diadakan di Kampus Prodi Arsitektur UMJ menghasilkan rumusan 2 kegiatan dari 2 aspek yang berbeda, yaitu:

1. Aspek Kesehatan Ibu, yaitu melalui penyuluhan kesehatan reproduksi dan keluarga, koordinator kegiatan BKKBN. Para ibu dan wanita di Desa Kiarasari dibekali pengetahuan mengenai kesehatan reproduksi sebagai upaya pencegahan pernikahan usia dini, perilaku seksual bebas, dan lain-lain (Widiyastuti \& Nurcahyani, 2019). Pemilihan metode penyuluhan karena dianggap cukup efektif dalam transfer pengetahuan praktis (Refdi et al., 2019). 
2. Aspek Pendidikan Anak, yaitu melalui pembuatan taman bermain anak koordinator kegiatan Prodi Arsitektur UMJ. Pemilihan taman bermain sebagai program aspek pendidikan anak karena bermain merupakan salah satu metode pembelajaran (Zaini, 2019). Taman bermain juga merupakan bentuk aktifitas fisik yang dapat mengurangi resiko penyakit degeneratif pada masa usia selanjutnya (Fitriani, Setyowati, \& Arumsari, 2020).

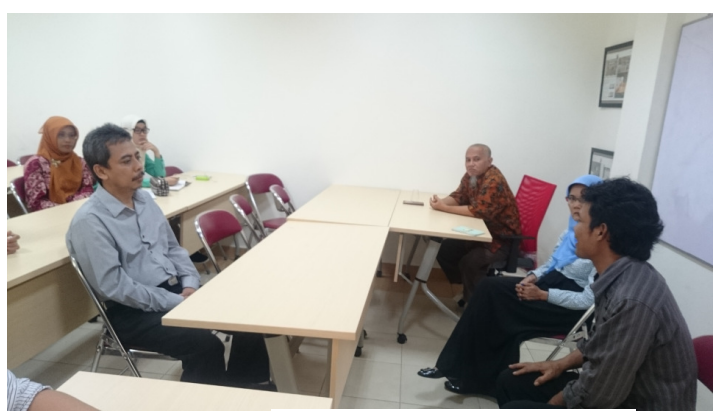

Gambar 1. Pertemuan Stakeholder

Sebelum waktu pelaksanaan kegiatan dilakukan tim internal melakukan survei lapangan untuk mengetahui kondisi lapangan. Pihak tim internal juga berkesempatan bertemu dengan tokoh dan pemerintah setempat untuk meminta izin dan menyampaikan program kegiatan pengabdian yang akan dilaksanakan.

Pada kesempatan ini tim internal bersama perwakilan warga Desa Kiarasari menentukan lokasi taman bermain yang akan dibangun. Taman bermain yang akan dibangun merupakan fasilitas publik maka lokasi yang dipilih adalah ruang terbuka yang berada dalam pemukiman warga dan dekat dengan fasilitas publik (Hantono \& Aziza, 2020). Setelah melakukan diskusi ringan dan observasi lokasi akhirnya dipilih lokasi yang berdekatan dengan sekolah Madrasah Ibtidaiyah Nurul Huda II Dusun Gunung Leutik Desa Kiarasari. Lokasi taman bermain tersebut merupakan ruang terbuka publik yang dapat dengan mudah diakses oleh masyarakat dari segala usia (Pramitasari \& Sarwadi, 2015). Nilai lebih dari lokasi ini adalah adanya taman bacaan yang telah terbangun terlebih dahulu sehingga diharapkan antar kedua taman ini saling memberi manfaat yang baik. Hibriditas ruang dan aktivitas antara bermain dan belajar diharapkan membawa dampak yang baik bagi penduduk setempat (Endangsih, Prayitno, \& Kusumawanto, 2020).

\section{Tahapan Pelaksanaan}

Pelaksanaan kegiatan pengabdian masyarakat ini dilaksanakan di Desa Kiarasari Kabupaten Bogor yang berlokasi di Dusun Gunung Leutik. Tim internal dan eksternal berangkat bersama dari Kampus Fakultas Teknik UMJ. Pada saat tiba di Dusun Gunung Leutik Desa Kiarasari seluruh tim telah disambut oleh beberapa tokoh masyarakat, perwakilan pegawai pemerintah daerah Desa Kiarasari, dan penduduk setempat. Sebelum acara inti dimulai dilakukan beberapa kata sambutan dan saling tukar cinderamata.

Kegiatan pengabdian masyarakat ini dibuka dengan penyuluhan kesehatan reproduksi dan keluarga yang disampaikan oleh perwakilan BKKBN, dalam hal ini dr. Noer Aziza. Materi yang disampaikan cukup antusias diterima oleh para ibu Desa 
Kiarasari. Hal ini tergambar dari sikap mereka yang terus memperhatikan materi yang disampaikan dan adanya beberapa pertanyaan yang diajukan oleh para ibu tersebut. Kegiatan ini diselingi dengan kuis berhadiah untuk melihat pemahaman mereka terhadap materi yang diberikan.

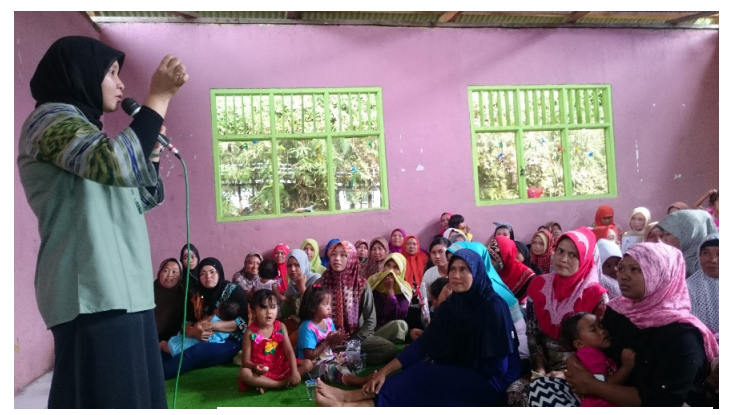

Gambar 2. Penyuluhan kesehatan ibu oleh BKKBN

Kegiatan pengabdian masyarakat dilanjutkan dengan pembuatan taman bermain yang dilengkapi dengan beberapa alat permainan di ruang terbuka. Alat permainan yang dipilih adalah alat yang aman digunakan oleh anak-anak serta bentuk dan warna yang dapat mengundang kreativitas mereka. Unsur-unsur elemen pada ruang terbuka juga dapat mempengaruhi kualitas visual ruang tersebut (Hantono \& Hakim, 2019). Pada saat kegiatan pengabdian masyarakat ini dilaksanakan seluruh alat bermain dalam kondisi belum terpasang. Pada kegiatan ini pembuatan taman bermain diisi oleh acara peletakan batu pertama yang dilakukan oleh Ketua Prodi Arsitektur UMJ, perwakilan BKKBN, dan perwakilan tokoh masyarakat setempat.

Seluruh rombongan juga berkesempatan melihat taman bacaan yang masih berada dalam satu kawasan ruang terbuka tersebut.
Taman bacaan ini berupa bangunan permanen yang berukuran $3 \mathrm{mX} 4 \mathrm{~m}$ dilengkapi dengan ruang buku, ruang baca, dan teras baca. Bangunan dan koleksi buku yang ada pada taman bacaan ini merupakan sumbangan yang didapat oleh warga Dusun Gunung Leutik. Pada saat melakukan survei awal sebelum kegiatan pengabdian dilaksanakan jumlah pengunjung taman bacaan terlihat sepi, hanya terlihat satu atau dua orang anak yang duduk membaca buku yang terdapat pad ataman bacaan tersebut.

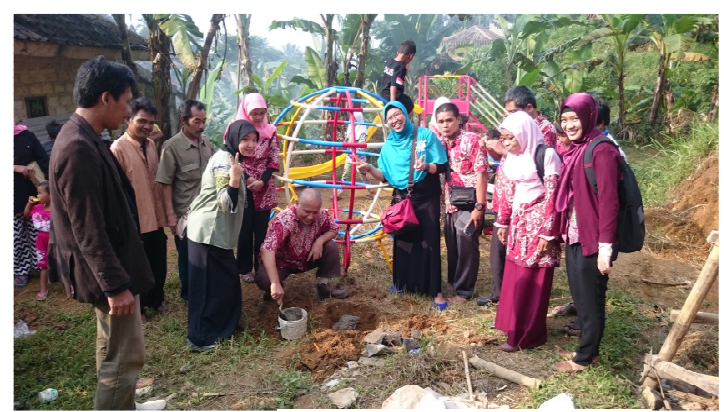

Gambar 3. Peletakan batu pertama pembuatan taman bermain

\section{Tahap Evaluasi}

Tahapan ini dilakukan setelah 1 bulan kegiatan pengabdian masyarakat selesai dilaksanakan. Pada tahap ini tim internal melihat pemanfaatan taman bermain sangat diminati oleh anak-anak warga sekitar. Observasi terhadap jumlah kunjungan ini tidak bisa dilakukan langsung oleh tim internal karena kendala jarak dan keterbatasan waktu. Pemantauan dibantu oleh salah satu tokoh masyarakat setempat untuk melihat jumlah kunjungan taman bermain yang telah dibuat.

Hasil dari pantauan tersebut didapat jumlah pengunjung pada taman bermain yang terus meningkat dari waktu ke waktu (Gambar 4). Peningkatan jumlah pengunjung 
pada taman bermain memberi pengaruh yang baik pula pada taman bacaan yang berada di dekatnya. Jumlah pengunjung pada taman bacaan juga mengalami kenaikan walaupun belum menyamai tingkat kenaikan pada taman bermain.

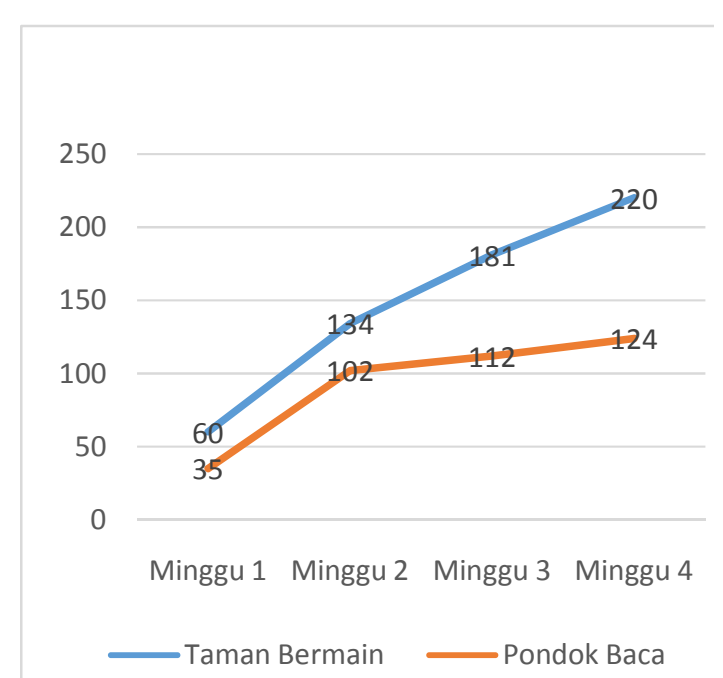

Gambar 4. Jumlah pengguna taman bermain dan taman bacaan

\section{KESIMPULAN}

Pembekalan pengetahuan dengan metode penyuluhan masih cukup dirasakan efektif diterima oleh seluruh peserta yang hadir. Pengadaan kuis berhadiah sebagai selingan menjadikan penyuluhan berlangsung lebih responsif dan memberikan umpan balik kepada penyuluh mengenai pemahaman peserta terhadap materi yang diberikan.

Pembuatan taman bermain sangat disenangi oleh anak-anak, baik para siswa Madrasah Ibtidaiyah Nurul Huda II maupun anak-anak Dusun Gunung Leutik Desa Kiarasari lainnya. Jumlah pengguna taman bermain semakin meningkat selama sebulan setelah taman bermain selesai dibangun. Kenaikan jumlah pengguna ini juga meberi dampak terhadap kenaikan jumlah pengunjung taman bacaan yang masih berada dalam satu lokasi yang sama.

\section{UCAPAN TERIMAKASIH}

Pada kesempatan ini penulis mengucapkan terima kasih kepada semua pihak yang terlibat pada kegiatan Pengabdian Masyarakat Program Studi Arsitektur Universitas Muhammadiyah Jakarta (UMJ) terutama kepada Badan Kependudukan dan Keluarga Berencana Nasional (BKKBN) Pusat yang telah membantu berupa materil maupun non materil, diantaranya: ide, tenaga, penyuluhan, dan dana untuk pelaksanaan kegiatan ini. Semoga kegiatan pengabdian ini dapat membawa manfaat kepada banyak pihak dan kerjasama yang terjalin ini dapat dilanjutkan pada kegiatankegiatan berikutnya.

\section{REFERENSI}

Ayuningtias, N., Pujiono, M., Nasution, V. A., \& Nasution, E. H. (2019). Pembelajaran Bahasa Mandarin Anak Usia Dini di Yayasan Pendidikan Islam Ar-Rahmah. LOGISTA - Jurnal Ilmiah Pengabdian kepada Masyarakat, 3(2), 105-113.

https://doi.org/10.25077/logista.3.2.105113.2019

Bussa, B. D., Bunga, B. N. K., Thoomaszen, F. W., \& Kiling, I. Y. (2018). Persepsi Ayah Tentang Pengasuhan Anak Usia Dini. Jurnal Sains Psikologi, 7(2), 126135.

https://doi.org/10.17977/um023v7i22018 p126

Diansyah, Simamora, V., Lukiyana, \& Silalahi, E. E. (2018). Program Pengabdian Kepada Masyarakat: Peran Koperasi Dalam Pemberdayaan Masyarakat Melalui Pengelolaan Bank Sampah pada Kampung Gunung Leutik Desa Kiarasari Kecamatan Sukajaya Kabupaten Bogor Jawa Barat. Jurnal Berdikari, 1(2), 37-42.

Endangsih, T., Prayitno, B., \& 
Kusumawanto, A. (2020). Sustainable Hybrid Village: Regeneration of Settlement in Jatinegara, Indonesia. In IOP Conference Series: Earth and Environmental Science (Vol. 520, hal. 1-7). IOP Publishing. https://doi.org/10.1088/17551315/520/1/012019

Fitriani, A., Setyowati, Y. D., \& Arumsari, I. (2020). Peningkatan Pengetahuan dan Perilaku Aktifitas Fisik Siswa Sekolah Dasar Melalui Edukasi Berbasis Praktik. JMM (Jurnal Masyarakat Mandiri), 4(4), 560-569. https://doi.org/10.31764/jmm.v4i4.2361

Hantono, D., \& Aziza, N. (2020). Peran Ruang Publik pada Kantor Rukun Warga Terhadap Aktivitas Masyarakat di Kelurahan Kebon Pala Jakarta Timur. Jurnal Arsitektur Alur, 3(2), 44-52. https://doi.org/10.17605/jalur.v3i2.899

Hantono, D., \& Hakim, A. H. (2019). Identifikasi Elemen Fisik Ruang Publik yang Berpengaruh Terhadap Pembentukan Visual Kawasan Kota Tua Jakarta. Jurnal Emara, 5(2), 75-79. https://doi.org/10.29080/eija.v5i2.879

Kawulur, A., Dengo, S., \& Rompas, S. P. (2015). Peranan BKKBN dalam Pembangunan Kesejahteraan Sosial (Suatu Studi di Badan Keluarga Berencana, Pemberdayaan Perempuan dan Perlindungan Anak Kabupaten Minahasa Selatan). Jurnal Administrasi Publik, 1(010), 1-13.

Oktomalioputri, B., \& Darwin, E. (2019). Edukasi Kesehatan Reproduksi Remaja Generasi Z dengan Metode Edugame di Sma 1 Batang Anai, Pariaman. LOGISTA - Jurnal Ilmiah Pengabdian kepada Masyarakat, 3(2), 46-51. https://doi.org/10.25077/logista.3.2(JulDes).46-51.2019

Pramitasari, D., \& Sarwadi, A. (2015). A
Study on Elderly's Going Out Activities and Environment Facilities. In Procedia Environmental Sciences (Vol. 28, hal. 315-323). Elsevier BV. https://doi.org/10.1016/j.proenv.2015.07. 040

Rafsyanjani, M. A., Rahmah, A. A., Wati, G. L., \& Hantono, D. (2020). Persepsi Masyarakat Terhadap Pemanfaatan Ruang di Pasar Kencar Jakarta Barat. Jurnal Arsitektur dan Perencanaan (JUARA), 3(2), 153-159. https://doi.org/10.31101/juara.v3i2.1328

Refdi, C. W., Novelina, N., Ismed, I., Syukri, D., Rasdiana, F. Z., \& Wellyalina, W. (2019). IbDM Pemanfaatan Teknologi Dalam Pengembangan Produk "Atun" sebagai Olahan Khas Nagari Lubuk Besar, Kabupaten Dharmasraya. LOGISTA - Jurnal Ilmiah Pengabdian kepada Masyarakat, 3(2), 199-205. https://doi.org/10.25077/logista.3.2.199205.2019

Syaharuddin, S., Pramita, D., \& Sirajuddin, S. (2019). Pengenalan Operasi Tambah Kurang Melalui Permainan Congklak Bagi Siswa Sekolah Dasar . JMM (Jurnal Masyarakat Mandiri), 3(1), 0106.

https://doi.org/10.31764/jmm.v3i1.900

Widiyastuti, D., \& Nurcahyani, L. (2019). Pengaruh Sapa Orangtua Remaja Terhadap Pengetahuan, Sikap dan Perilaku Oangtua tentang Pendidikan Kesehatan Reproduksi. Jurnal Kesehatan Reproduksi, 6(3), 93-98. https://doi.org/10.22146/jkr.45496

Zaini, A. (2019). Bermain sebagai Metode Pembelajaran bagi Anak Usia Dini. ThufuLA: Jurnal Inovasi Pendidikan Guru Raudhatul Athfal, 3(1), 118-134. https://doi.org/10.21043/thufula.v3i1.46 56 